Quantitative Political Economy Research Group

Department of Political Economy

King's College London

\title{
QPE
}

\section{The effect of COVID-19 lockdowns on political support: Some good news for democracy?}

QPE Working Paper 2020-1

(Version 3)

Damien Bol

Marco Giani

André Blais

Peter John Loewen

May 23, 2020 


\title{
The EFFECT OF COVID-19 LOCKDOWNS ON POLITICAL
}

\author{
SUPPORT: SOME GOOD NEWS FOR DEMOCRACY?
}

Damien Bol; Marco Giani† André Blais; and Peter John Loewen ${ }^{\S}$

Accepted for publication in the

European Journal of Political Research

\begin{abstract}
Major crises can act as critical junctures or reinforce the political status quo, depending on how citizens view the performance of central institutions. We use an interrupted time series to study the political effect of the enforcement of a strict confinement policy in response to the COVID-19 pandemic. Specifically, we take advantage of a unique representative web-based survey that was fielded in March and April 2020 in Western Europe to compare the political support of those who took the survey right before and right after the start of the lockdown in their country. We find that lockdowns have increased vote intentions for the party of the Prime Minister/President, trust in government, and satisfaction with democracy. Furthermore, we find that, while rallying individuals around current leaders and institutions, they have had no effect on traditional left-right attitudes.
\end{abstract}

*Associate Professor, King's College London, damien.bol@kcl.ac.uk.

$\dagger$ 'Assistant Professor, King's College London, marco.giani@kcl.ac.uk.

${ }^{\ddagger}$ Professor, Université de Montréal, andre.blais@umontreal.ca.

$\S$ Professor, University of Toronto, peter.loewen@utoronto.ca. 
Acknowledgement: This study used a dataset co-funded by a group of scholars from KC London, U de Montréal, U of Toronto, UL Bruxelles, Karlstads U, U Wien, Sciences Po Paris, UC Riverside, UC Dublin, U Helsinki, and U Pompeu Fabra. Damien Bol would like to thank Célyne Van Corven for accepting to fully take care of their baby for two extra days, so that he could work on this paper. Also, he would like to thank Alice for being kind enough to her mum during that time. Damien Bol and Marco Giani contributed equally to this work. 


\section{INTRODUCTION}

The 2020 COVID-19 pandemic poses an unprecedented challenge to established democracies. Governments face an apparent tradeoff between a large number of deaths and an economic shutdown. In response, most countries have enforced strict social confinement measures unthinkable outside war times, and usually referred to as 'lockdowns'. Although there seems to be a consensus that such policies are the most effective means to reduce the incidence of severe acute respiratory syndrome coronavirus 2 (SARS-CoV-2), which causes coronavirus disease 2019 (COVID-19), they also strongly reduce civil liberties, erode social capital and bring about economic insecurity (Fetzer el al 2020). Hence, whether and how lockdowns affect political attitudes is far from being trivial.

As emphasized by Stephens (2020) in the Financial Times, we observe, amid the COVID-19 pandemic, "the return of government to centre stage [that] marks the close of an era in which power and responsibility migrated from states to markets." In this new era, a key question emerges: when confronted with grave threats such as those caused by a major health crisis, do citizens trust the democratic system to respond? To answer this question, we study the short-term effects of lockdowns on political attitudes in the context of Western European democracies. In particular, we investigate public support for decision makers, institutions and regimes. Such support, specifically directed towards political actors and more diffuse towards the political system, is key for the good functioning of democracy (Easton 1975; Claassen 2020).

Major international crises can act as critical junctures or reinforce the status quo depending on how well-established institutions perform, and how citizen perceive this performance. In this paper, we aim to speak to the literature on policy feedback that explores the loop from policies to mass attitudes, and to policies again (for a review, see Campbell 2012), by focusing on the effect of the main policy response to the COVID-19 pandemic, i.e. lockdowns. This literature has shown that the policies adopted in response to a major crisis can affect political 
support. First, they can rally citizens around the Head of the State when these citizens perceive that the policies indeed help solve the issue or at least bring some relief (e.g., Bechtel \& Hainmueller 2011; Healy \& Malhotra 2009). This mechanism of retrospective performance evaluation leads to accountable governments. Second, they can alter support for institutions by shifting citizens' views about these institutions, which can in turn lead to regime change (e.g., Aidt \& Leon 2016; Ruiz-Rufino \& Alonso 2017).

Unsurprisingly, there is so far no consensus in the literature about the political consequences of the COVID-19 crisis. In a recent working paper, Leininger and Shaub (2020) exploit variations in the number of confirmed cases at the county level in Bavaria and show that the health crisis has benefited the dominant party. In a series of survey experiments and analysis of social media data in Canada, Merkley et al (2020) find that the pandemic has been associated with greater partisan consensus and support for the government (see also Harell 2020, and Hargreaves Heap et al 2020 in the United Kingdom). These studies suggest that the COVID-19 crisis has been reinforcing the democratic status quo. Yet, in a working paper that focuses on Spain, Amat et al (2020) combine several pieces of experimental evidence to show that it has induced a strong national bias coupled with higher demands for techno-authoritarian decision-making. These results suggest that the the crisis may mark the beginning of a paradigmatic shift in terms of democratic attitudes. In another working paper focusing on the United States, Gadarian et al (2020) analyze responses to a unique survey experiment and find that support for strict confinement measures is strongly rooted in partisanship. Similarly, Grossman et al (2020) analyze social media data and show that the partisan affiliation of the Governor who announced local lockdowns is also key to explaining public compliance to these lockdowns. We seek to contribute to this emerging literature by focusing on how lockdowns have affected political support across Western European countries in the days that followed their enforcement.

Using data from a unique online survey fortuitously fielded throughout the months of March and April 2020 on representative samples of the population of 15 Western European 
countries, a period in which seven countries started a national lockdown, we compare the political attitudes of respondents who filled in the questionnaire right before the enforcement date and those who did right after. ${ }^{1}$ We find that lockdowns have increased support for the status quo decision makers, institutions and regimes. The vote intentions for the party of the Prime-Minister/President have gone up by about 4\%, and trust in government and satisfaction with democracy by about $3 \%$ on the response's scale. ${ }^{2}$ However, consistently with the study of Gadarian et al (2020), we find that lockdowns have had no effect on self-reported ideology. Furthermore, there little evidence of a rally-around-the-flag effect (Hetherington \& Nelson 2003; Mueller 1970) that would be entirely driven by the pandemic itself and its incidence. Overall, our study thus confirms the retrospective evaluation of performance mechanisms: it seems that citizens have understood that lockdowns were necessary and rewarded those responsible for them.

\section{DATA AND TREATMENT VARIABLE}

Our main dataset comes from a web-based survey that took about 15 minutes to complete. ${ }^{3}$ The questionnaire included questions about political attitudes and preferences for electoral outcomes. It was fielded between March 2 and April 3 in 15 Western European countries (i.e., the 15 members of the European Union prior the 2004 enlargement except Luxembourg, but with the addition of Norway), seven of which started a lockdown during the temporal interval of the survey. The dataset can thus be seen as an interrupted time series. To identify the confinement measures, as well as their enforcement dates, we rely on the data gathered by

\footnotetext{
${ }^{1}$ Such 'Unexpected Event during Survey Design' (Muñoz et al 2018) is increasingly popular in political science and economics. It has been recently applied to study the effect of terrorist attacks (Larsen et al 2020), foreign electoral outcomes (Giani \& Méon 2019), or even football games (Depetris-Chauvin et al 2020) on political attitudes.

${ }^{2}$ When we include all governing parties as well as junior coalition partners, the effect of lockdowns on vote intentions for parties in power reaches $6 \%$.

${ }^{3}$ Note that the web-based nature of the survey is important here. A face-to-face survey would have been interrupted with the enforcement of a lockdown. Our online survey continued as usual.
} 
Hale et al (2020). ${ }^{4}$ In this dataset, lockdowns are defined as nationwide and strictly enforced social confinement, i.e., citizens are forced (not simply encouraged) to stay home unless they have a valid reason to travel. According to this definition, a lockdown was enforced in Austria (March 16), Denmark (March 18), France (March 17), Italy (March 13), the Netherlands (March 24), Spain (March 15), and the United Kingdom (March 23). In the main analysis, we only include these seven countries. To reduce noise in the estimates, we do not include countries in which the containment policy was decided at the subnational level like Germany. Yet, in a robustness test, we include the other countries, and find that the results are essentially similar (see Appendix A.2).

From March 2 onward, we contracted the survey firm DyNata to contact a sample of 1,000 adults representative of the population of each country in terms of age, gender, and education attainment. In such a survey, not all respondents fill in the questionnaire on the same day. The reason has to do with the way survey firms operate. They usually have a large database with the email addresses of potential respondents together with some sociodemographic information about them. On Day 1, they send an email with a link to the survey to a first set of potential respondents and make sure that their sociodemographic distributions match the one in the latest census data of the country. Of course, not everybody takes the survey on the same day, and some decide not to take it at all. Then, the survey firm sends another email to a second set of potential respondents a few days later. This operation is repeated until the sample reaches the targeted number of respondents. In our survey, it took until April 3 to achieve this goal. ${ }^{5}$

A consequence of the survey firm's sampling strategy is that we have in our sample re-

\footnotetext{
${ }^{4}$ Note that in a supplementary test, we reproduce the analysis with the announcement date of the lockdowns instead of their enforcement date. To identify the announcement date, we rely on the dataset of Cheng et al (2020).

${ }^{5}$ Appendix A.1 shows the evolution of the daily number of respondents in the seven countries included in the main analysis. It gives a visual representation of the waves in which the surveys were sent to respondents. When we group all seven countries and look at the number of respondents relative to the lockdown enforcement date (which varies depending on the country), we see that the distribution stretches over the whole survey period, with a concentration around this date.
} 
spondents who were invited to complete the survey before the lockdown enforcement date, and others who were invited to complete it afterwards. As a consequence of this, we have respondents who completed the survey before the lockdown, and other respondents who completed it after. This is our treatment variable. Note that we do not assume that respondents who filled in the questionnaire before the enforcement date did not expect a lockdown. The virus had already reached Europe at the time, and the policy was already common in other affected countries like China. Yet, the key difference between the 'treated' and 'non-treated' respondents is that only the latter witnessed the government adopting strict confinement measures. Furthermore, Appendix A.2 shows that, in our sample, those who responded before and after the enforcement date are very similar on all socio-demographic variables that we can access (age, gender, education level, rurality, and immigration background). In a series of supplementary tests, we also show that they are similar on unrelated political attitudes like ideology and political interest. Hence, although the lockdown was expected, the probability of taking the survey before or after it seems to be 'as good as random'. In the rest of the paper, we thus talk about the effect of lockdowns on political support, treating this as an effective causal identification.

\section{OUTCOME VARIABLES}

We focus on three key outcome variables that pertain to different aspects of political support. In line with Easton's (1975) classic typology, we include indicators of both specific (i.e., related to an actor or a set of actors) and diffuse support (i.e., related to an institution or a regime). First, we estimate the effect of lockdowns on the probability to report, in the survey, a vote intention for the party of the current Prime Minister (or President in the case of France). We see this variable as an indicator of specific support. It is also in line with studies of the rally effect following a major event like a terrorist attack (e.g., Hetherington \& Nelson 2003). ${ }^{6}$

\footnotetext{
${ }^{6}$ The governing coalitions (and Prime Minister/President) are: Austria: ÖVP (PM), Grüne; Denmark: Social Democrats (PM); France LREM (President); Italy: M5S, PD; Netherlands: VVD (PM), CDA, D66;
} 
The results are similar, although slightly larger. Second, we estimate the effect of lockdowns on variables capturing more diffuse political support. In particular, we use the reported levels of trust in government (on a scale from 0 to 4), and satisfaction with democracy (on a scale from 1 to 11) in the survey. Note that the variable trust in government can be seen as either specific or diffuse support, depending on whether the respondent understood the term 'government' as referring to the current composition of the government or the institution.

We also include two extra outcome variables in the survey to run some supplementary tests: left-right ideology (1-11) and political interest (0-3). A priori, these political attitudes should not be affected by lockdowns, since they result from a long-term socialization process and are quite stable over time (Evans, Heath, \& Lalljee 1996; Prior 2019). The question wording of the five outcome variables and descriptive statistics can be found in Appendix A.1. We recode all of them to vary between 0 and 1 to facilitate the interpretation of the results.

\section{RESUlts}

We use OLS regressions and four specifications to estimate the effects of lockdowns on political attitudes. They are all based on the following equation:

$$
y_{i, c, t}=\alpha+\beta \times \operatorname{Lockdown}_{i, c, t}+\gamma \operatorname{Deaths}_{c, t}+\psi T_{i, c}+\phi \mathbf{z}_{\mathbf{i}, \mathbf{c}, \mathbf{t}}+\theta_{c}+\mu_{i, c, t} .
$$

Our outcome variable is $y_{i, c, t}$. It refers to respondent refers to individual $i$ in country $c$ at time $t$ (=day of filling the survey). $\alpha$ is the intercept. Lockdown is a dummy variable taking the value of 1 if the individual was surveyed after the enforcement date in country $c$ and zero if it was before it. $\beta$ is the main coefficient of interest, i.e., the lockdown effect. We introduce country fixed effects $\theta_{c}$ and as an idiosyncratic error term $\mu_{i, c, t}$. We cluster robust errors at

Spain: PSOE (PM), Podemos, UK: Conservatives (PM). Italy has a non-partisan Prime Minister and it is excluded from the analysis of vote intentions for the party of the Prime Minister/President. In Appendix A.2, we reproduce the analysis with a variable capturing a vote intention for the parties of the governing coalition. 
the country-day level to account for unobserved heterogeneity over time and space. This is the Basic specification.

We further estimate an Extended specification, in which we account for the progressing incidence of COVID-19 spread by controlling for the number of deaths attributed to the virus as reported in official statistics in country $c$ at time $t\left(\gamma\right.$ Deaths $\left._{c, t}\right)$. The number of confirmed cases has a correlation $\rho=.95$ with the number of deaths. We thus exclude it to avoid multicollinearity. In addition, we introduce a time trend $T_{i, c}$, consisting in the number of days since the start of the survey in March 2, to disentangle the time-varying dynamic of political support during the pandemic from the lockdown itself.

In a third Full specification we introduce $\mathbf{z}_{\mathbf{i}, \mathbf{c}, \mathbf{t}}$, a vector of control variables, all measured in the survey. It includes gender (0-Male, 1-Female), age (15-99), rurality (0-Urban, 1-Rural), immigration background (0-Not born in the country, 1-Born in the country), education level (0-No university degree, 1-University degree), and electoral participation (0-Not voted at last election, 1-Voted at last election). The descriptive statistics of all these control variables can be found in Appendix A.1. 


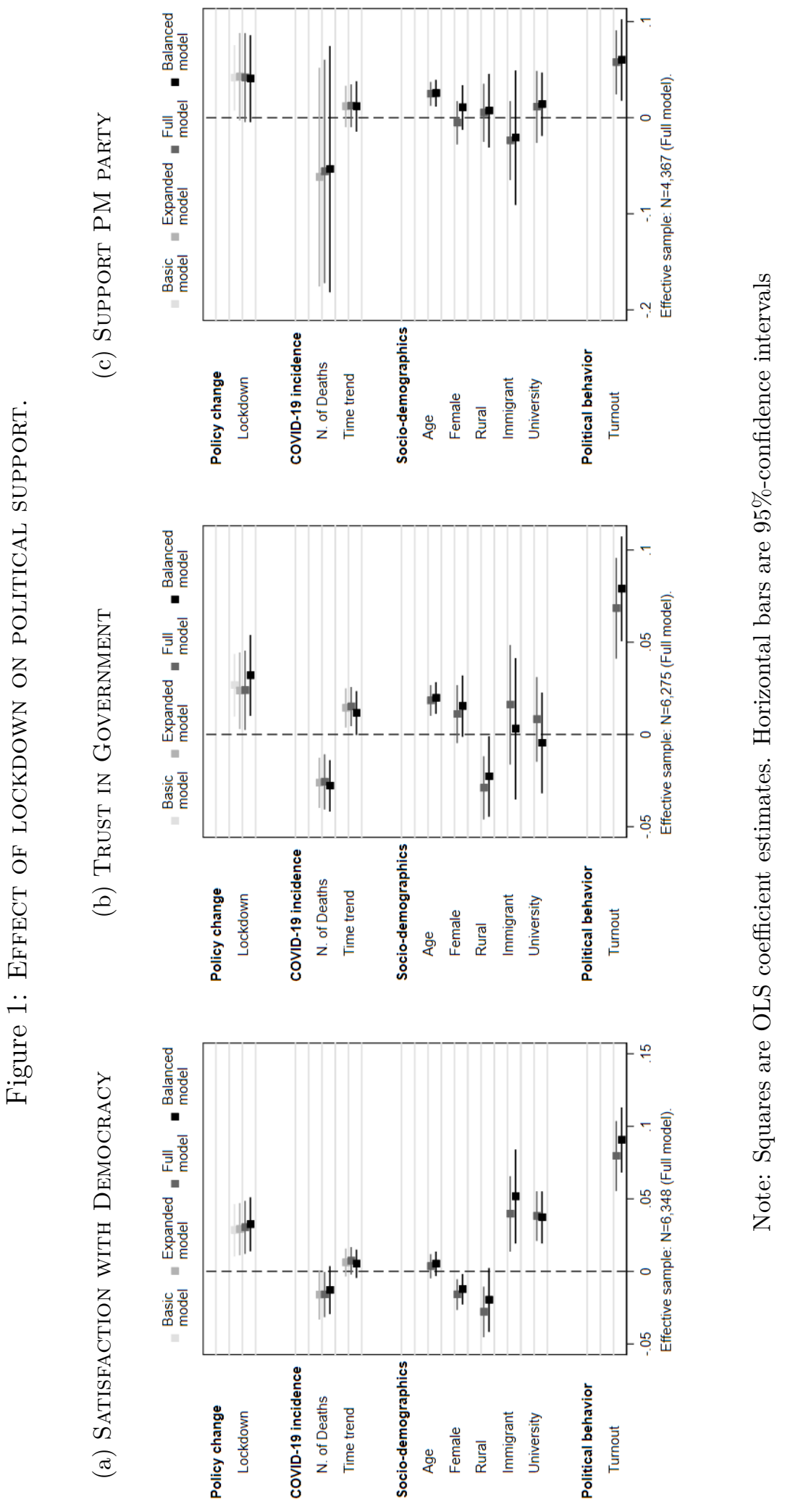


Fourth, we also estimate a Balanced specification. This specification is similar to the Full one, except that we first use entropy balancing (Hainmueller 2012) to reduce any imbalance between respondents interviewed before or after the interview. Although imbalance is relatively small (see Appendix A.1), we can still correct for it to increase internal validity. Concretely entropy balancing weights the distribution of covariates among non-treated respondents to make it mimic the first and second moment of the equivalent distribution among treated respondents.

Figure 1 presents the regression results of the four specifications. ${ }^{7}$ First, it shows that lockdowns have increased satisfaction with democracy by $2.8-3.2 \%$ and trust in government by $2.4-3.2 \%$ on the full response's scale (from the minimum to the maximum). Second, it shows that they have also increased vote intentions for the party of the Prime Minister/President between $4.1 \%$ and $4.3 \%$. This effect reaches $6 \%$ points when we consider all governing parties (see Appendix A.2). These short-term effects are most of the time statistically significant at least at a level of $p<0.05$. Appendix A.2 show the results for the two extra outcomes. It points towards a non-ideological lockdown effect: the policy has not affected neither left-right ideology, nor political interest. The coefficients of interest are extremely close to 0 , and never statistically significant.

We conduct a series of supplementary tests to assess the robustness of the results. They are all described in Appendix A.2. First, we reproduce the analysis in adding the remaining countries covered by the original survey. Second, we remove, one-by-one, each of the seven countries of the main analysis to make sure that the results are not solely driven by one of them. In both instances, the results are very similar. Third, we reproduce the analysis in changing the treatment variable by other policy responses of smaller scale to COVID-19 pandemic, i.e. school closure and workplace closure. We find a null effect. ${ }^{8}$ This test shows

\footnotetext{
${ }^{7}$ Note that to facilitate interpretation, all continuous control variables (number of deaths, age, and time trend) are standardized so that their mean is 0 and their standard deviation is 1

${ }^{8}$ Our interpretation of this null effect is that while lockdown concerns everybody, and quite unambiguously decrease everyone's welfare by harming social capital as well as the economy, neither school nor workplace closures have consequences of the same magnitude. As well as this, only full lockdowns also have a symbolic
} 
that among all policies enforced in March 2020, only the most emblematic one, the lockdown, has had an effect on political support. Fourth, we conduct a permutation test to ensure that our results are not due to chance. For this test, we reproduce the analysis in randomly assigning a lockdown enforcement date to one of the dates of the survey. Out of 1,000 iterations, we observe that the placebo lockdown effect is almost always null.

Finally, we discuss the mechanism that we believe is likely to explain the positive lockdown effect on political support. First, we consider the possibility of a rally-around-the-flag effect, according to which it is the health crisis itself, and its incidence, that has increased political support. Such an effect is common after a major crisis like a terrorist attack (Hetherington \& Nelson 2003; Mueller 1970, for some counter evidence, see Balcells \& Torrats-Espinosa 2018). Yet, if there was such an effect in data, we should observe positive coefficients associated with the time trend variable and/or the one associated with the number of deaths. Figure 1 reveals that there is a small positive coefficient for time (not statistically significant), and a negative one for the number of deaths (not statistically significant). There is thus little of the existence of a rally-around-the-flag effect in the temporal interval of the survey. Second, we consider the possibility that the increase in political support is due to an increased airtime of the Prime-Minister/President. Indeed, the introduction of lockdowns usually went along with televised statements followed by unusually large shares from the public. In Appendix A.2, we report an extra test, in which we change the independent variable to capture whether the respondents were surveyed before or after the announcement of the lockdown by the Prime-Minister/President in the media. We find a positive effect on political support, but not a statistically significant one. This suggests that the expectation of the policy is not enough to spur policy support. All in all, we believe that the most likely mechanism is retrospective performance evaluation, according to which citizens have had to understand that strict social confinement measures were necessary and have increased their support for those responsible nature: they mean reducing the freedom of movement, which is often considered as one of the most important civil liberty. 
for this policy.

\section{Discussion}

In this research note, we analyze the responses to a survey conducted in several West European countries in March 2020, the month in which most governments made the difficult choice to enforce a strict containment to limit the spread of the COVID-19 virus. Although this policy has important negative consequences for the population, both human and economic, we find that respondents who took the survey right after the enforcement date show higher levels of both specific and diffuse political support than those who took it right before. First, lockdowns have increased vote intentions for the party of the Prime Minister/President by about $4 \%$ points. Second, they increased trust in government and satisfaction with democracy by about $3 \%$ on the response's scale. These effects are particularly interesting when considering that these two groups of respondents are very similar in terms of socio-demographics and unrelated political attitudes like ideology and political interest. We also find little evidence that this effect is simply due to a rally-around-the-flag effect brought about by the health crisis itself and its incidence.

Our findings bring some good news. It seems that citizens have undersood that strict social containment was necessary, and have rewarded governments that decide to enforce it, at least in the short term. Furthermore, our findings suggest that it has had a positive spill-over effect on support for democracy and its institutions. Perhaps, this is due to the realization that governments were ready to make hard decisions which have prioritized the health of vulnerable individuals over economic interests. Whether this allows sustained action against COVID-19 virus remains to be seen. Yet, it seems that this pandemic has maybe offered the opportunity to reconcile part of the population with its political leaders and democratic institutions. 


\section{REFERENCES}

Aidt, T.S. \& Leon, G. (2016). The Democratic Window of Opportunity: Evidence from Riots in Sub-Saharan Africa. Journal of Conflict Resolution 60(4): 694-717.

Amat, F., Arenas, A., Faló-Gimeno, A. \& Muñoz, J. (2020). Pandemics Meet Democracy: Experimental Evidence from the COVID-19 Crisis in Spain. arXiv Working Paper. Available at: https://osf.io/preprints/socarxiv/dkusw/.

Balcells, L. \& Torrats-Espinosa, G. (2018). The Electoral Consequences of Terrorism. Evidence from a Natural Experiment. Proceedings of the National Academy of Sciences 115(42): 10624-10629.

Bechtel, M.M. \& Hainmueller, J. (2011). How Lasting Is Voter Gratitude? An Analysis of the Short- and Long-Term Electoral Returns to Beneficial Policy. American Journal of Political Science 55(4): 852-868.

Campbell, A.L. (2012). Policy Makes Mass Politics. Annual Review of Political Science 15(1): 333-351.

Cheng, C., Barcelo, J., Hartnett, A. Kubinec, R. \& Messerschmidt, L. (2020). CoronaNet: A Dyadic Dataset of Government Responses to the COVID-19 Pandemic. arXiv Working Paper. Available at: https://osf.io/preprints/socarxiv/dkvxy/.

Claassen, C. (2020). Does Public Support Help Democracy Survive? American Journal of Political Science 64(1): 118-134.

Depetris-Chauvin, E., Durante, R. \& Campante, F. (2020). Building Nations through Shared Experiences: Evidence from African Football. American Economic Review 110(5): $1572-1602$. 
Easton, D. (1975). A Re-Assessment of the Concept of Political Support. British Journal of Political Science 5(4): 435-457.

Evans, G., Heath, A. \& Lalljee, M. (1996). Measuring Left-Right and LibertarianAuthoritarian Values in the British Electorate. British Journal of Sociology 47(1): 93-112.

Fetzer, T., Hensel, L., Hermle, J. \& Roth, C. (2020). Coronavirus Perceptions and Economic Anxiety. arXiv Working Paper. Available at: https://arxiv.org/abs/2003.03848.

Gadarian, S.K., Goodman, S. \& Pepinsky, T.B. (2020). Partisan Endorsement Experiments Do Not Affect Mass Opinion on COVID-19. SSRN Working Paper. Available at: https://ssrn.com/abstract=3574605.

Giani, M. \& Méon, P.G. (2019). Global Racist Contagion Following Donald Trump's Election. British Journal of Political Science 1-8. Available at https://doi.org/10.1017/S0007123419000449.

Grossman, G., Kim, S., Rexer, J. \& Thirumurthy, H. (2020). Political Partisanship Influences Behavioral Responses to Governors? Recommendations for COVID-19 Prevention in the United States. SSRN Working Paper. Available at: ihttps : //papers.ssrn.com/sol3/papers.cfm?abstract ${ }_{d}=3578695$.

Hainmueller, J. (2012). Entropy Balancing for Causal Effects: A Multivariate Reweighting Method to Produce Balanced Samples in Observational Studies. Political Analysis 20(1): $25-46$.

Hale, T., Webster, A. Petherick, A., Phillips, T. \& Kira, B. (2020). Oxford COVID-19 Government Response Tracker, Blavatnik School of Government. Data use policy: Creative Commons Attribution CC BY standard. Available at: https://www.bsg.ox.ac.uk/research/research-projects/coronavirus-governmentresponse-tracker. 
Harell, A. (2020). How Canada's Pandemic Is Shifting Political Views. Report for the Institute for Research on Public Policy. Available at https://policyoptions.irpp.org/fr/magazines/avril-2020/how-canadas-pandemicresponse-is-shifting-political-views/.

Hargreaves Heap, S., Koop, C., Matakos, K., Unan, A., and Weber, N. (2020). COVID-19 and People's Health-Wealth Preferences: Information Effects and Policy Implications. QPE Working Paper 2020-5. Available at https://osf.io/preprints/socarxiv/mz67j/.

Healy, A. \& Malhotra, N. (2009). Myopic Voters and Natural Disaster Policy. American Political Science Review 103(3): 387-406.

Hetherington, M.J.\& Nelson, M. (2003). Anatomy of a Rally Effect: George W. Bush and the War on Terrorism. PS: Political Science \& Politics 36(1): 37-42.

Larsen, E.G., Cutts, D. \& Goodwin, M.G. (2020). Do Terrorist Attacks Feed Populist Eurosceptics? Evidence from Two Comparative Quasi-Experiments. European Journal of Political Research 59(1):182-205.

Leininger, A., \& Shaub, M. (2020). Voting at the dawn of a global pandemic. arXiv Working Paper. Available at: https://osf.io/preprints/socarxiv/a32r7.

Muñoz, J., Falcó-Gimeno, A. \& Hernández, E. (2018). Unexpected Event during Survey Design: Promise and Pitfalls for Causal Inference. Political Analysis 1-21.

Merkley, E., Bridgeman, A., Loewen, P.J., Owen, T., Ruths, D. \& Zhilin, O. (2020). A Rare Moment of Cross-Partisan Consensus: Elite and Public Response to the COVID-19 Pandemic in Canada. Canadian Journal of Political Science, First View.

Mueller, J.E. (1970). Presidential Popularity from Truman to Johnson. American Political Science Review 64(1): 18-34. 
Prior, M. (2019). Hooked: How Politics Captures People's Interest. Cambridge University Press.

Ruiz-Rufino, R. \& Alonso, S. (2017). Democracy Without Choice: Citizens' Perceptions of Government's Autonomy during the Euro-Zone Crisis. European Journal of Political Research 56(2): 230-245.

Stephens, P. (2020). How Coronavirus is Remaking Democratic Politics. The Financial Times. Available at: https://www.ft.com/content/0e83be62-6e98-11ea-89df-41bea055720b/. 


\section{A APPEndix}

\section{A.1 Descriptive information}

. Figure A.1 plots the daily collection of responses to the online survey. The black dashed line is the day at which the lockdown was enforced. The first graph on the top left group all countries together. As the reader can see, a high percentage of responses (about 2/3) are collected within two days before and after the lockdown date. This gives us some confidence about attributing the observed outcomes to the lockdown policy.

- Table A.1 gives the descriptive statistics of for all outcome and control variables used in the analysis. It also separates respondents who filled the survey before and after the lockdown enforcement date. It thus also informs us about sample's imbalance. This imbalance seems rather moderate for some most variables including age, gender, rurality, and electoral behavior. It is slightly larger for education, which could bias our estimates. This is why we use a specification that weights observations through entropy balancing (so called Balance specification).

. The question wording for the outcome variables is the following:

Satisfaction with democracy: On the whole, how satisfied are you with the way democracy works in [country], on a 0 to 10 scale? (1-Not satisfied at all, 11- Extremely satisfied).

Trust in government: Could you tell us how much you agree/disagree with the following statements: I trust the government to do the right thing? (0-Strongly disagree, 1-Somewhat disagree, 2-Neither agree nor disagree, 3-Somewhat agree, 4-Strongly agree). 
Vote intentions: If there was an election today, which party would you vote for?

Ideology: In politics people sometimes talk of "left" and "right". Where would you place yourself? (1-Extreme left, 11-Extreme right).

Interest in politics: How interested would you say you are in politics? (0-Not at all interested, 1-Hardly interested, 2-Quite interested, 3-Very interested). 


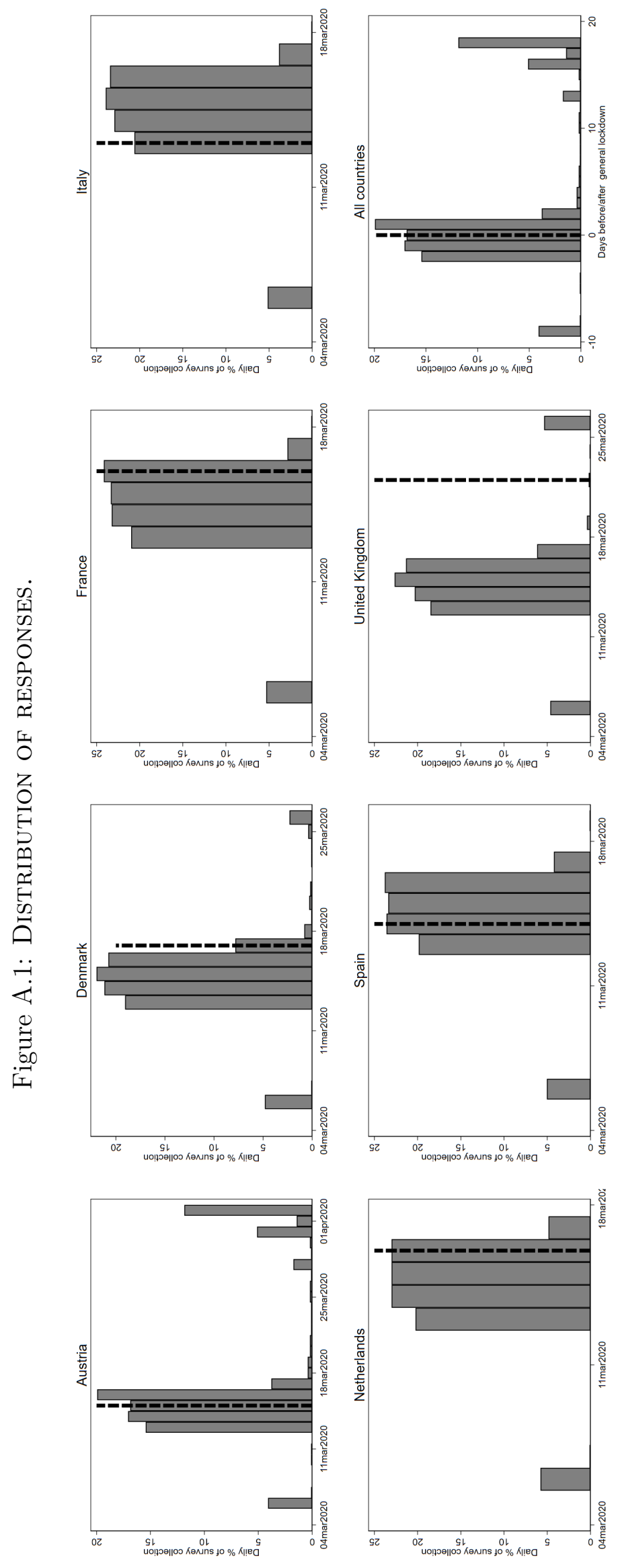




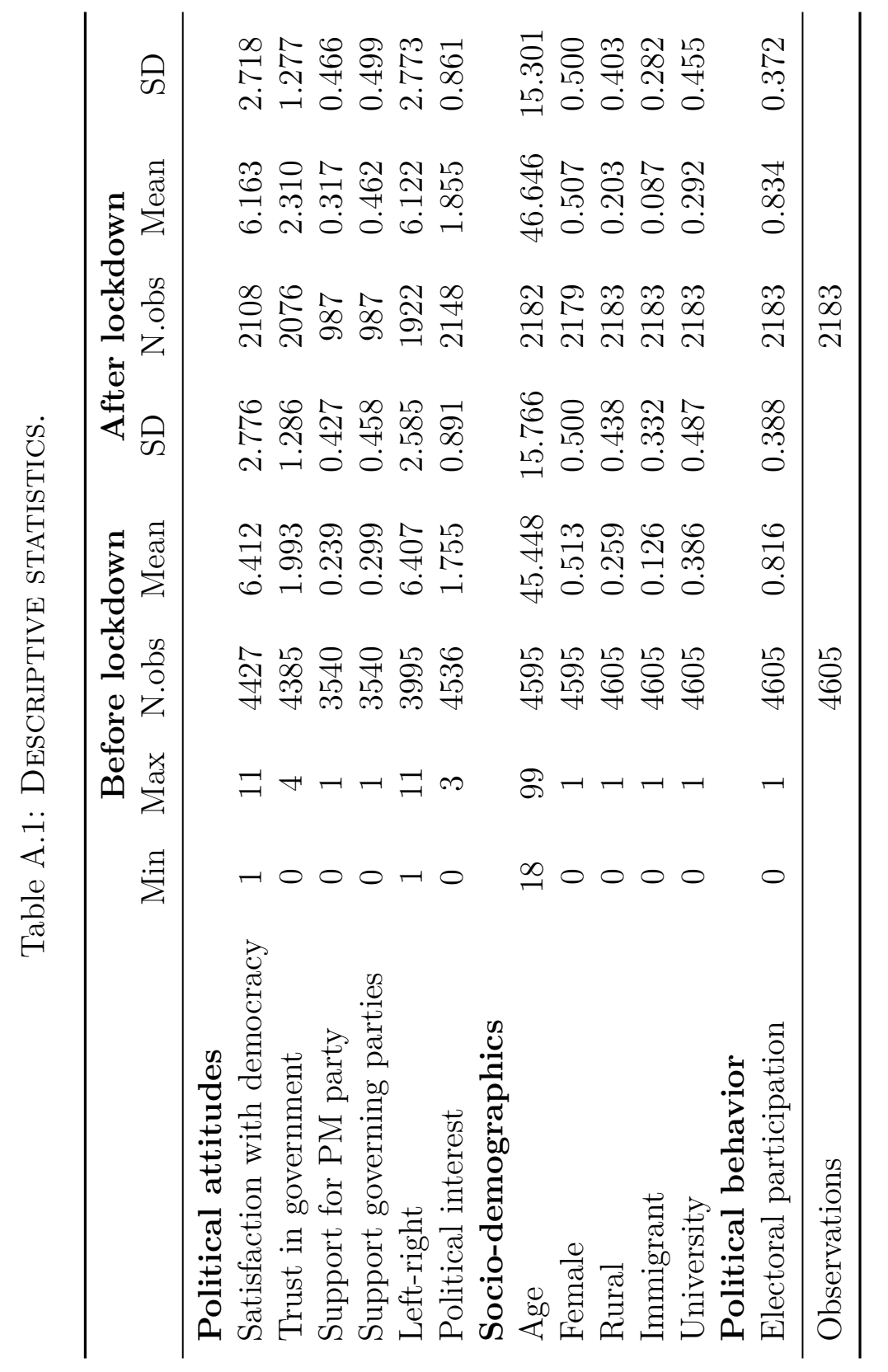




\section{A.2 Robustness tests}

- Table A.2 prints coefficients and key statistics relative to the analysis of the Full specification presented in Figure 1. The outcome variables of columns (a) (b) and (c) are the same as those in Figure 1. The outcome variables of columns (d) and (e) are, respectively, left-right self-positioning and political interest.

- Table A.3 prints coefficients and key statistics relative to the analysis the Full specification presented in Figure 1, but in which we include all 15 countries of the original survey. The results are similar to those of Figure 1.

. Figure A.2 plots the results of the permutation test that aims at checking against the presence of a false positive lockdown effect created by chance (or other). We create 'placebo lockdown dates' in assigning it, by country, to a random date within the temporal interval of the survey. We then reproduce the analysis of the Full specification with this new treatment variable. We re-iterate this procedure 1,000 times. Figure A.2 plots the placebo lockdown effects for each of the main outcome variables. The vertical dashed line is the original lockdown effect for the sake of comparison. The reader can see that the original lockdown effect is larger that almost all placebo lockdown effects. This confirms that our result is not a false positive, and not due to chance.

- Figure A.3 plots the estimated lockdown effect of the analysis of the Full specification presented in Figure 1, but in which which we delete one of the seven countries at the time. The results are similar to those of Figure 1. They show that lockdown effects are not systematically driven by one country. However, they highlight that while satisfaction for democracy is robust to the deletion of any country, both trust in government and support for the PM/President party sometimes lose statistical significance at a level of $p<0.05$, depending on which country is deleted. Yet, the magnitude is always positive, and the magnitude is rather constant. 
- Table A.4 prints coefficients and key statistics relative to the analysis of the Full specification presented in Figure 1, but in which we transform the treatment variable so that it differentiates respondents who were surveyed before and after the lockdown announcement date (instead of lockdown enforcement date). The lockdowns were typically announced a few days before their enforcement (March 10 in Austria, March 11 in Denmark, March 16 in France, March 9 in Italy, March 13 in Spain, March 15 in the Netherlands, and March 23 in the United Kingdom). The results reveal that the announcement effect is smaller than the enforcement effect (see Figure 1), and not statistically significant at a level of $p<0.1)$

- Tables A.5 and A.6 print coefficients and key statistics relative to the analysis of the Full specification presented in Figure 1, but in which we change the treatment variable for the enforcement date of softer policies (school closing and workplace closing, respectively). The results are null. 
Table A.2: Effect of LOCKDown on political Support (Full Results).

\begin{tabular}{|c|c|c|c|c|c|c|}
\hline & \multicolumn{4}{|c|}{ Political support } & \multicolumn{2}{|c|}{ Placebo } \\
\hline & $\mathrm{a}$ & $\mathrm{b}$ & c & $\mathrm{d}$ & $\mathrm{e}$ & $\mathrm{f}$ \\
\hline Lockdown & $\begin{array}{c}0.303^{* * *} \\
(0.090)\end{array}$ & $\begin{array}{c}0.096^{* *} \\
(0.046)\end{array}$ & $\begin{array}{c}0.042^{*} \\
(0.023)\end{array}$ & $\begin{array}{c}0.064^{* *} \\
(0.025)\end{array}$ & $\begin{array}{c}0.021 \\
(0.079)\end{array}$ & $\begin{array}{c}-0.006 \\
(0.031)\end{array}$ \\
\hline N. of Deaths & $\begin{array}{c}-0.160^{* *} \\
(0.068)\end{array}$ & $\begin{array}{c}-0.103^{* * *} \\
(0.032)\end{array}$ & $\begin{array}{c}-0.000 \\
(0.000)\end{array}$ & $\begin{array}{c}-0.000^{*} \\
(0.000)\end{array}$ & $\begin{array}{c}-0.244^{* *} \\
(0.095)\end{array}$ & $\begin{array}{l}-0.005 \\
(0.041)\end{array}$ \\
\hline Time trend & $\begin{array}{c}0.073^{* *} \\
(0.032)\end{array}$ & $\begin{array}{c}0.060^{* *} \\
(0.023)\end{array}$ & $\begin{array}{c}0.003 \\
(0.003)\end{array}$ & $\begin{array}{c}0.003 \\
(0.004)\end{array}$ & $\begin{array}{c}-0.005 \\
(0.047)\end{array}$ & $\begin{array}{l}-0.015 \\
(0.011)\end{array}$ \\
\hline Age & $\begin{array}{c}0.035 \\
(0.022)\end{array}$ & $\begin{array}{c}0.074^{* * *} \\
(0.016)\end{array}$ & $\begin{array}{c}0.002^{* * *} \\
(0.000)\end{array}$ & $\begin{array}{l}0.001^{* *} \\
(0.001)\end{array}$ & $\begin{array}{c}0.052 \\
(0.036)\end{array}$ & $\begin{array}{c}0.051^{* * *} \\
(0.014)\end{array}$ \\
\hline Female & $\begin{array}{c}-0.160^{* * *} \\
(0.051)\end{array}$ & $\begin{array}{c}0.044^{* * *} \\
(0.015)\end{array}$ & $\begin{array}{c}-0.005 \\
(0.011)\end{array}$ & $\begin{array}{c}-0.009 \\
(0.012)\end{array}$ & $\begin{array}{c}-0.310^{* * *} \\
(0.074)\end{array}$ & $\begin{array}{c}-0.303^{* * *} \\
(0.022)\end{array}$ \\
\hline Rural & $\begin{array}{c}-0.279^{* * *} \\
(0.087)\end{array}$ & $\begin{array}{c}-0.116^{* *} \\
(0.046)\end{array}$ & $\begin{array}{c}0.005 \\
(0.015)\end{array}$ & $\begin{array}{c}-0.003 \\
(0.016)\end{array}$ & $\begin{array}{c}-0.043 \\
(0.101)\end{array}$ & $\begin{array}{c}-0.137^{* * *} \\
(0.026)\end{array}$ \\
\hline Immigrant & $\begin{array}{c}0.396^{* * *} \\
(0.116)\end{array}$ & $\begin{array}{c}0.064 \\
(0.051)\end{array}$ & $\begin{array}{l}-0.024 \\
(0.021)\end{array}$ & $\begin{array}{c}-0.028 \\
(0.018)\end{array}$ & $\begin{array}{c}0.161 \\
(0.118)\end{array}$ & $\begin{array}{c}0.050 \\
(0.038)\end{array}$ \\
\hline University & $\begin{array}{c}0.381^{* * *} \\
(0.048)\end{array}$ & $\begin{array}{c}0.033 \\
(0.044)\end{array}$ & $\begin{array}{c}0.011 \\
(0.019)\end{array}$ & $\begin{array}{c}0.021 \\
(0.020)\end{array}$ & $\begin{array}{c}-0.133 \\
(0.091)\end{array}$ & $\begin{array}{c}0.241^{* * *} \\
(0.029)\end{array}$ \\
\hline Turnout & $\begin{array}{c}0.795^{* * *} \\
(0.083)\end{array}$ & $\begin{array}{c}0.274^{* * *} \\
(0.055)\end{array}$ & $\begin{array}{c}0.058^{* * *} \\
(0.017)\end{array}$ & $\begin{array}{c}0.049^{* * *} \\
(0.019)\end{array}$ & $\begin{array}{l}0.251^{* *} \\
(0.107)\end{array}$ & $\begin{array}{c}0.660^{* * *} \\
(0.032)\end{array}$ \\
\hline Country FE & Yes & Yes & Yes & Yes & Yes & Yes \\
\hline COVID-19 incidence & Yes & Yes & Yes & Yes & Yes & Yes \\
\hline Controls & Yes & Yes & Yes & Yes & Yes & Yes \\
\hline N.obs & 6,348 & 6,275 & 4,367 & 4,367 & 5,745 & 6,495 \\
\hline R-squared & 0.115 & 0.056 & 0.035 & 0.055 & 0.036 & 0.163 \\
\hline
\end{tabular}

Notes. ${ }^{*} p<0.10,{ }^{* *} p<0.05,{ }^{* * *} p<0.01$. We report OLS coefficients, standardized for Age, N. of deaths and Time trend. Robust standard errors are clustered at country-day level. 
Table A.3: Effect of lockdown on political support: Full sample.

\begin{tabular}{lccc}
\hline \multirow{4}{*}{ Lockdown } & \multicolumn{3}{c}{ Political support } \\
& $0.029^{* * *}$ & $0.021^{* *}$ & $0.049^{*}$ \\
N. of Deaths & $(0.010)$ & $(0.010)$ & $(0.025)$ \\
& $-0.000^{*}$ & $-0.000^{* * *}$ & -0.000 \\
Time trend & $(0.000)$ & $(0.000)$ & $(0.000)$ \\
& $0.001^{* *}$ & $0.003^{* * *}$ & $0.002^{*}$ \\
Age & $(0.001)$ & $(0.001)$ & $(0.001)$ \\
& -0.000 & $0.000^{* *}$ & $0.002^{* * *}$ \\
Female & $(0.000)$ & $(0.000)$ & $(0.000)$ \\
Rural & $-0.013^{* * *}$ & 0.005 & 0.000 \\
& $(0.004)$ & $(0.006)$ & $(0.008)$ \\
Immigrant & $-0.032^{* * *}$ & $-0.026^{* * *}$ & 0.002 \\
& $(0.006)$ & $(0.006)$ & $(0.010)$ \\
University & $-0.053^{* * *}$ & $-0.035^{* * *}$ & $0.024^{*}$ \\
Turnout & $(0.009)$ & $(0.010)$ & $(0.013)$ \\
& $0.043^{* * *}$ & $0.026^{* * *}$ & 0.013 \\
R-squared & $(0.006)$ & $(0.007)$ & $(0.012)$ \\
Country FE & $0.077^{* * *}$ & $0.065^{* * *}$ & $0.037^{* * *}$ \\
COVID-19 incidence & $(0.008)$ & $(0.009)$ & $(0.011)$ \\
\hline Nontrols & Yes & Yes & Yes \\
Yes & Yes & Yes & Yes \\
& 14,049 & 13,908 & 10,652 \\
& 0.088 & 0.052 & 0.046 \\
\hline
\end{tabular}

Notes. ${ }^{*} p<0.10,{ }^{* *} p<0.05,{ }^{* * *} p<0.01$. We report OLS coefficients, standardized for Age, N.of deaths and Time trend. Robust standard errors are clustered at country-day level. 
Figure A.2: Permutation test
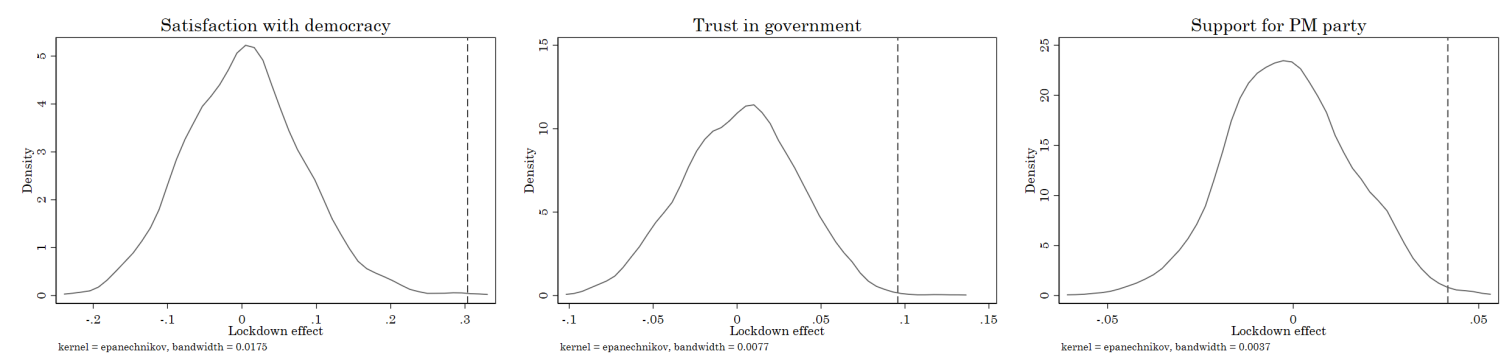
Figure A.3: Country SEnsitivity Analysis.
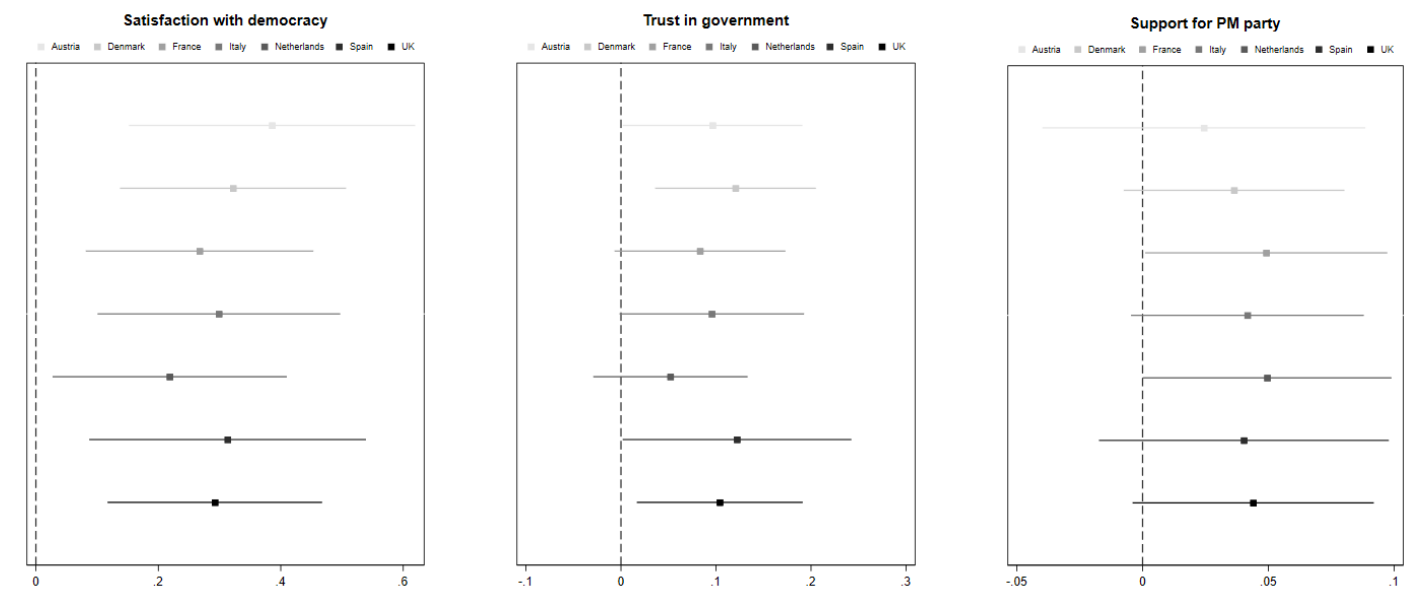
Table A.4: EFFECT of LOCKDOWn ANNOUnCEMENTS ON POLITICAL SUPPORT.

\begin{tabular}{|c|c|c|c|}
\hline & \multicolumn{3}{|c|}{ Political support } \\
\hline & a & $\mathrm{b}$ & $\mathrm{c}$ \\
\hline Lockdown announcement & $\begin{array}{c}0.009 \\
(0.012)\end{array}$ & $\begin{array}{c}0.017 \\
(0.013)\end{array}$ & $\begin{array}{c}0.021 \\
(0.020)\end{array}$ \\
\hline N. of Deaths & $\begin{array}{c}-0.012^{* *} \\
(0.006)\end{array}$ & $\begin{array}{c}-0.023^{* *} \\
(0.010)\end{array}$ & $\begin{array}{c}-0.060 \\
(0.051)\end{array}$ \\
\hline Time trend & $\begin{array}{c}0.010 \\
(0.006)\end{array}$ & $\begin{array}{c}0.014 \\
(0.008)\end{array}$ & $\begin{array}{c}0.015 \\
(0.016)\end{array}$ \\
\hline Age & $\begin{array}{c}0.004 \\
(0.002)\end{array}$ & $\begin{array}{c}0.018^{* * *} \\
(0.004)\end{array}$ & $\begin{array}{c}0.018^{* *} \\
(0.008)\end{array}$ \\
\hline Female & $\begin{array}{c}-0.016^{* * *} \\
(0.005)\end{array}$ & $\begin{array}{c}0.011^{* * *} \\
(0.004)\end{array}$ & $\begin{array}{l}-0.009 \\
(0.012)\end{array}$ \\
\hline Rural & $\begin{array}{c}-0.028^{* * *} \\
(0.009)\end{array}$ & $\begin{array}{c}-0.029^{* *} \\
(0.011)\end{array}$ & $\begin{array}{c}-0.003 \\
(0.017)\end{array}$ \\
\hline Immigrant & $\begin{array}{c}0.040^{* * *} \\
(0.012)\end{array}$ & $\begin{array}{c}0.016 \\
(0.013)\end{array}$ & $\begin{array}{c}-0.028 \\
(0.019)\end{array}$ \\
\hline University & $\begin{array}{c}0.038^{* * *} \\
(0.005)\end{array}$ & $\begin{array}{c}0.008 \\
(0.011)\end{array}$ & $\begin{array}{c}0.020 \\
(0.020)\end{array}$ \\
\hline Turnout & $\begin{array}{c}0.080^{* * *} \\
(0.008) \\
\end{array}$ & $\begin{array}{c}0.068^{* * *} \\
(0.014) \\
\end{array}$ & $\begin{array}{c}0.050^{* * *} \\
(0.019) \\
\end{array}$ \\
\hline Country FE & Yes & Yes & Yes \\
\hline COVID-19 incidence & Yes & Yes & Yes \\
\hline Controls & Yes & Yes & Yes \\
\hline N.obs & 6,348 & 6,275 & 4,367 \\
\hline R-squared & 0.114 & 0.055 & 0.054 \\
\hline
\end{tabular}

Notes. ${ }^{*} p<0.10,{ }^{* *} p<0.05,{ }^{* * *} p<0.01$. We report OLS coefficients, standardized for Age, N.of deaths and Time trend. Robust standard errors are clustered at country-day level. 
Table A.5: Effect of School Closing.

\begin{tabular}{|c|c|c|c|}
\hline & \multicolumn{3}{|c|}{ Political support } \\
\hline & $\mathrm{a}$ & $\mathrm{b}$ & $\mathrm{c}$ \\
\hline School closing & $\begin{array}{c}0.009 \\
(0.011)\end{array}$ & $\begin{array}{c}0.002 \\
(0.011)\end{array}$ & $\begin{array}{l}-0.000 \\
(0.017)\end{array}$ \\
\hline N. of Deaths & $\begin{array}{l}-0.010 \\
(0.008)\end{array}$ & $\begin{array}{l}-0.022^{*} \\
(0.012)\end{array}$ & $\begin{array}{l}-0.018 \\
(0.048)\end{array}$ \\
\hline Time trend & $\begin{array}{c}0.008 \\
(0.008)\end{array}$ & $\begin{array}{c}0.018^{*} \\
(0.009)\end{array}$ & $\begin{array}{c}0.017 \\
(0.014)\end{array}$ \\
\hline Age & $\begin{array}{c}0.004 \\
(0.002)\end{array}$ & $\begin{array}{c}0.018^{* * *} \\
(0.004)\end{array}$ & $\begin{array}{c}0.025^{* * *} \\
(0.006)\end{array}$ \\
\hline Female & $\begin{array}{c}-0.016^{* * *} \\
(0.005)\end{array}$ & $\begin{array}{c}0.011^{* * *} \\
(0.004)\end{array}$ & $\begin{array}{l}-0.006 \\
(0.011)\end{array}$ \\
\hline Rural & $\begin{array}{c}-0.028^{* * *} \\
(0.009)\end{array}$ & $\begin{array}{c}-0.029^{* *} \\
(0.011)\end{array}$ & $\begin{array}{c}0.005 \\
(0.015)\end{array}$ \\
\hline Immigrant & $\begin{array}{c}0.040^{* * *} \\
(0.012)\end{array}$ & $\begin{array}{c}0.016 \\
(0.013)\end{array}$ & $\begin{array}{c}-0.023 \\
(0.021)\end{array}$ \\
\hline University & $\begin{array}{c}0.038^{* * *} \\
(0.005)\end{array}$ & $\begin{array}{c}0.008 \\
(0.011)\end{array}$ & $\begin{array}{c}0.011 \\
(0.019)\end{array}$ \\
\hline Turnout & $\begin{array}{c}0.080^{* * *} \\
(0.008)\end{array}$ & $\begin{array}{c}0.068^{* * *} \\
(0.014)\end{array}$ & $\begin{array}{c}0.058^{* * *} \\
(0.017)\end{array}$ \\
\hline Country FE & Yes & Yes & Yes \\
\hline COVID-19 incidence & Yes & Yes & Yes \\
\hline Controls & Yes & Yes & Yes \\
\hline N.obs & 6,348 & 6,275 & 4,367 \\
\hline R-squared & 0.114 & 0.055 & 0.035 \\
\hline
\end{tabular}


Table A.6: Effect of Workplace Closing.

\begin{tabular}{lccc}
\hline & \multicolumn{3}{c}{ Political support } \\
& $\mathrm{a}$ & $\mathrm{b}$ & $\mathrm{c}$ \\
\hline Workplace & 0.002 & 0.008 & 0.021 \\
closing & $(0.006)$ & $(0.007)$ & $(0.013)$ \\
N. of Deaths & -0.011 & $-0.021^{* *}$ & -0.053 \\
& $(0.009)$ & $(0.010)$ & $(0.043)$ \\
Time trend & 0.010 & $0.015^{*}$ & 0.012 \\
& $(0.008)$ & $(0.008)$ & $(0.011)$ \\
Age & 0.003 & $0.017^{* * *}$ & $0.024^{* * *}$ \\
& $(0.004)$ & $(0.004)$ & $(0.006)$ \\
Female & $-0.017^{* * *}$ & 0.011 & -0.006 \\
& $(0.005)$ & $(0.008)$ & $(0.011)$ \\
Rural & $-0.027^{* * *}$ & $-0.027^{* * *}$ & 0.006 \\
& $(0.009)$ & $(0.009)$ & $(0.015)$ \\
Immigrant & $0.039^{* * *}$ & 0.015 & -0.028 \\
& $(0.013)$ & $(0.016)$ & $(0.021)$ \\
University & $0.038^{* * *}$ & 0.009 & 0.012 \\
& $(0.009)$ & $(0.012)$ & $(0.019)$ \\
Turnout & $0.080^{* * *}$ & $0.069^{* * *}$ & $0.056^{* * *}$ \\
& $(0.012)$ & $(0.014)$ & $(0.017)$ \\
\hline Country FE & Yes & Yes & Yes \\
COVID-19 incidence & Yes & Yes & Yes \\
Controls & Yes & Yes & Yes \\
N.obs & 6,271 & 6,196 & 4,298 \\
\hline Notes. & 0.112 & 0.056 & 0.035 \\
\hline
\end{tabular}

Notes. ${ }^{*} p<0.10,{ }^{* *} p<0.05,{ }^{* * *} p<0.01$. We report OLS coefficients, standardized for Age, N.of deaths and Time trend. Robust standard errors are clustered at country-day level. 